\title{
KULT TRZYGŁAWA W SZCZECINIE LAT DWUDZIESTYCH XII STULECIA. MIĘDZY MONOLATRIĄ A „DWUWIARĄ"1
}

\author{
CULT OF TRIGLAV IN SZCZECIN IN THE 1120S. \\ BETWEEN MONOLATRY AND "RELIGIOUS DUALISM"
}

\begin{abstract}
The cult of Triglav in the Polabian-Pomeranian territory in the $12^{\text {th }}$ century confirms an evolution of the religious system of the local Slavic communities towards monolatry, largely affected by confrontation as well as a cultural dialogue with the Christian culture. At first, at the time of the Pomeranian missions of Saint Otto of Bamberg in the 1120s, attempts at suppressing the cult did not bring about long-term effects. However, a wave of the so-called pagan reaction led to some sort of a compromise made in Szczecin, leading to official coexistence of the cult of Triglav and the newly introduced cult of Jesus Christ. From the point of view of mythology, the competences of the two divine figures turn out to be convergent and universal, yet still, as part of the Szczecin "religious dualism", no attempt was made to identify them (following the rule of interpretatio Slavica of the elements of Christianity). The belief in the autonomy of Triglav and Christ ("A German God") was confirmed in Szczecin in the course of Otto's evangelization which resulted in a Christian community in the city. The phenomenon of syncretism, present there until Otto's second mission (1128), was therefore an attempt at maintaining unity in a religiously divided society following the first mission of the Apostle of Pomeranians (1124-1125).
\end{abstract}

Keywords: religion of Slavs, syncretism, Christianization, life of Saint Otto from Bamberg, Triglav.

Trzygław stanowi jedyne $\mathrm{z}$ bóstw Pomorzan poświadczone z imienia w najdawniejszych i najbardziej wiarygodnych, powstałych do XII w., przekazach źródłowych (zob. np. Strzelczyk 2008, s. 215-217). Należy jednak zaznaczyć, że tak określana zbiorowość zamieszkująca między Bałtykiem a Notecią oraz Wisłą i Odrą ${ }^{2}$ stanowiła konglomerat wielu społeczności plemiennych postrzeganych - od

* ORCID 0000-0002-6051-0788, Instytut Historyczny, Uniwersytet Wrocławski, ul. Szewska 49, 50-139 Wrocław, e-mail: stanislaw.rosik@uwr.edu.pl.

${ }^{1}$ Artykuł powstał w ramach Programu Narodowego Programu Rozwoju Humanistyki - Projekt Badawczy pt. „Polska i Pomorze w kształtowaniu cywilizacji europejskiej (od słowiańskich plemion do przełomu XII/XIII w.)” (umowa nr 0110/NPRH3/H12/82/2014).

${ }^{2}$ Czytelne świadectwo Adama z Bremy, który wskazał Odrę jako granicę między Lucicami a Pomorzanami (Adam II, 19; IV, 13). 
XI w. - jako całość przede wszystkim z zewnątrz. „Plemię Pomorzan” (gens Pomeranorum), które nazwę otrzymało od mieszkańców względnie wąskiego pasa nadmorskiego, w kształcie znanym ze źródeł XII-wiecznych okazuje się bytem uformowanym w ramach procesów tworzenia już post-plemiennego świata, włączania wspomnianych plemiennych społeczności w ramy chrześcijańskich monarchii, począwszy do prób podejmowanych w tym zakresie przez pierwszych Piastów.

W tym kontekście, obserwowalne na podstawie źródeł z XI i XII w. ${ }^{3}$, wyznaczenie zachodniej granicy między Pomorzanami a Lucicami na Odrze trudno uznać za ostro zarysowaną linię podziału w wymiarze kulturowym, a samo dolne Nadodrze rysuje się jako strefa pod tym względem ściśle powiązana $\mathrm{z}$ kręgiem północnopołabskim. Konstatacja ta nabiera szczególnej wagi, gdy weźmie się pod uwagę nie tylko praktykowanie kultu Trzygława w XII w. również w Brennie (Brandenburgu) (Heinrici de Antwerpe Tractatus de captione urbis Brandenburgensis, s. 482), lecz także sam fakt wielogłowości jego posągu, a zatem wystąpienia charakterystycznej cechy idoli słowiańskich na Połabiu północnym z uwzględnieniem wiodącej pod tym względem wyspy Rugii (Rosik 1995; Miś 1997; Strzelczyk 2007, s. 159,174 i n., 207-210).

Kult Trzygława w Szczecinie został obalony podczas misji ewangelizacyjnej prowadzonej przez św. Ottona z Bambergu w latach 1124-1125, ale wkrótce - już po wyjeździe misjonarza z Pomorza - powrócił wraz z wygnanymi wcześniej pogańskimi kapłanami, aczkolwiek w synkretycznej formule: paralelnie do czci oddawanej na pogańską modłę Chrystusowi. Rekonwersja szczecinian podczas drugiej misji Ottona (1128) okazała się kluczem do pełni, trwałego już, sukcesu ewangelizacyjnego u Pomorzan (szeroko w tej sprawie: Rosik 2010, s. 102-510).

Względna łatwość oraz synkretyczny charakter, z jakimi doszło do restytucji kultu Trzygława, dają do myślenia nad specyfiką ówczesnych stosunków religijnych u ujścia Odry. Na nich właśnie koncentrują się niniejsze refleksje, a droga do ich poznania wiedzie przede wszystkim przez świat przedstawiony hagiografii Bamberczyka, analizowanej w szerszym kontekście źródeł narracyjnych i archeologicznych. Postulat ten nabiera szczególnej wagi z racji wprzężenia motywów literackich związanych ze wspomnianym bóstwem w odmienne strategie narracyjne przyjęte przez żywociarzy Ottona w kształtowaniu jego memorii, dodajmy, że jeszcze na etapie przedkanonizacyjnym (analizy zob. Rosik 2010, passim), w ciągu dwóch dekad po jego śmierci w 1139 roku$^{4}$.

\footnotetext{
${ }^{3}$ Dane Adama z Bremy (zob. wyżej przyp. 2) potwierdza raport Ottona z Bambergu z jego pierwszej wyprawy do Pomorzan (1124-1125) zamieszczony najpóźniej po roku w kronice Ekkeharda z Aura (zm. 1126), w którym misjonarz powiadamia, iż działał on na Pomorzu i w pewnych ośrodkach Luciców. W związku z tym, że jego akcja nie wykraczała na zachód poza Nadodrze, to rzeczywiście Odra rysuje się jako orientacyjna granica pomorsko-lucicka (zob. Ekkechardi Uraugiensis chronica, pod r. 1124, s. 263 i n.).

${ }^{4} \mathrm{O}$ chronologii powstania żywotów Ottona z przeglądem skrótowo literatury zob. m.in. Haarländer 2000, s. 527-535; Strzelczyk 2005, s. 18-19, 23-26.
} 
Najwcześniejszy $\mathrm{w}$ tryptyku tych dzieł żywot autorstwa anonimowego autora z Prüfening pod Ratyzboną, tzw. Vita Prieflingensis (VP), powstał najpewniej do roku $1146^{5}$, natomiast kolejne dwa stworzyli benedyktyni z Michelsbergu pod Bambergiem w szóstej dekadzie XII stulecia: najpierw Ebon (Ebo) ${ }^{6}$, a następnie - w konwencji dialogu - Herbord (Herbord) ${ }^{7}$. Obaj ostatni włączyli się swymi utworami w bieżącą środowiskową debatę nad reformą monastyczną. Kreacja osoby Ottona na scenie ich dzieł stanowi rodzaj zwierciadła, w którym odbijają się wyznawane przez nich ideały vita religiosa, a wyraźny rozdźwięk pojawił się między obu przekazami $\mathrm{w}$ odniesieniu do oceny znaczenia misji u pogan podjętych przez protagonistę

Ebon rozwinął obecną już w Vita Prieflingensis ideę uznania go za współuczestnika dzieła pierwszych uczniów Chrystusa (VP II 1; II, 17: vir apostolicus) na zasadzie zaliczenia go do ich grona jako Apostoła Pomorzan (zwłaszcza: Ebo III, $27)^{9}$, a tym samym ukazywał, że trwanie przy tradycyjnej w jego benedyktyńskim środowisku regule z Hirsau - warunkujące ją ideały realizować miał w doskonałym stopniu (niebędący zresztą mnichem) Otton - w pełni wystarcza na osiągnięcie chwały godnej pierwszych Apostołów. Herbord jednak nie podzielił tego poglądu. Owszem, nie odmawiał zasług misyjnych Ottonowi, ale bynajmniej nie równał ich z dokonaniami św. Piotra czy św. Pawła. Imponowały mu bowiem ówczesne ideały cysterskie i stąd za największy tytuł do otaczania Ottona kultem uznał jego troskę o klasztory, rozwój ich infrastruktury, pomnażanie ich majątku służącego ubogim i pięknu służby bożej (Rosik 2010, s. 538 i n.).

Herbord dowartościował na kartach swego dzieła w interpretacji misji u pogan kluczowe przesłanie Vita Prieflingensis, ukazującej jako ukoronowanie dzieła życia Ottona założenie nowego Kościoła pomorskiego. Autor Dialogu nie zapomniał jednak w tym kontekście - w zgodzie ze wspomnianą naczelną ideą promowaną w tym utworze - podkreślić, że pozyskana dla chrześcijaństwa Pomerania to dogodna przestrzeń dla budowy klasztorów. Obydwa te żywoty, czyli pierwszy i trzeci, łączy traktowanie pierwszej misyjnej wyprawy protagonisty jako przełomowej w dziele konwersji ,plemienia Pomorzan”, a drugiej już jedynie jako jego poszerzenie i utwierdzenie, zwłaszcza po nadszarpnięciu apostazją Szczecina ukazanego jako najważniejsze z miast Pomorza (Rosik 2010, s. 513 i n.).

Odmiennie postąpił Ebon, który wprowadził na scenę historii misji Ottona drugą, obok pomorskiej, gens Uznoim (,plemię uznamskie”) (Ebo III, 3), i dopiero jej konwersja wyznacza w jego dziele pełnię sukcesu apostolskiego głównego bo-

\footnotetext{
5 O autorze i dziele zob. m.in. Petersohn 1999, s. 1-43.

${ }^{6}$ Trwa dyskusja nad znajomością Vita Prieflingensis przez Ebona, aczkolwiek próby podważenia dominującego w literaturze pozytywnego sądu w tej sprawie (argumenty negatywne przytacza S. Haarländer, zob. wyżej, przyp. 3) są mało przekonujące w obliczu ewidentnych podobieństw obu utworów (Rosik 2010, s. 98 i n.).

7 O autorze i dziele zob. Liman 1975.

${ }^{8}$ Klasyczne studium tego zagadnienia: Demm 1970; zob. też Rosik 2010, s. 532 i n.

9 Podstawowe studium problemu: Petersohn 1966.
} 
hatera, aczkolwiek w połączeniu z rekonwersją apostackich po pierwszej misji Pomorzan. Tym samym dopiero druga podróż misyjna okazuje się w świetle narracji Ebona przełomem w nawracaniu nadbałtyckich pogan, co wzmocnił interpretacją apostazji Szczecina i - mniej docenionej przez dwóch pozostałych autorów - Wolina ${ }^{10}$ jako zasiania kąkolu między dobre ziarno. Zastosowanie tego nawiązania do ewangelicznej przypowieści miało dowodzić, iż odstępstwo skutkowało całkowitym unicestwieniem plonu pierwszej misji Ottona jako skażonego szerzącym się bałwochwalstwem (Ebo II, 18 i III, 3; Rosik 2010, s. 352 n.).

W Vita Prieflingensis, a następnie Dialogu Herborda, dwuwiara szczecinian ukazana została natomiast w nawiązaniu do starotestamentowej historii Samarytan, którzy połączyli cześć adresowaną do jedynego Boga z idolatrią (VP III, 5; Herbord III, 16). To porównanie uwydatnia niedoskonałość postawy religijnej pomorskich neofitów, ale nie oznacza całkowitego przekreślenia dokonań ewangelizacyjnych z czasu pierwszej misji Ottona. Stąd przybywając do nich ponownie, co podkreśla Herbord, miał on potraktować ich jako błądzących grzeszników i po zadaniu im odpowiedniej pokuty przez rytualne nałożenie rąk dokonać przywrócenia ich do wspólnoty kościelnej (Herbord III, 20).

Z perspektywy faktograficznej metafora „grzechu Samarytan” wydaje się celnie oddawać sytuację w Szczecinie na etapie apostazji, czyli koegzystencję kultów Chrystusa i Trzygława, ale z perspektywy teologii trudno podważać słuszność oceny Ebona. Podkreślał on, że rozszerzenie się takiej formy religijności oznacza fiasko ewangelizacji, gdyż nawet cześć oddawana Bogu chrześcijańskiemu na taką modłę oznaczała de facto bałwochwalstwo. Co istotne, spór między hagiografami toczy się jedynie o interpretację publicznie zaakceptowanej koegzystencji kultów Chrystusa i Trzygława w ramach jednej społeczności, która jednak sama w sobie okazuje się faktem solidnie potwierdzonym źródłowo.

Nie ma zgody między żywotami Ottona w sprawie umiejscowienia obu kultów - za uprawianiem ich w jednej świątyni opowiada się Vita Prieflingensis i Dialog Herborda, gdzie mowa o dostawieniu w kościele ołtarza dedykowanego idolom (VP III, 5; Herbord III, 16), natomiast Ebon napisał o dwóch osobnych przybytkach (Ebo III, 1). Kluczowe znaczenie dla niniejszych dociekań ma jednak sam fakt, iż ów co najwyżej 3-letni nawrót do rodzimej religii w Szczecinie dokonać się miał na zasadzie synkretycznej, a przy tym sami kustosze rodzimych instytucji kultowych - w źródłach ukazywani jako kapłani pogańscy - zdecydowali się otoczyć publicznym kultem obce dotąd (choć od pokoleń znane z racji sąsiedzkich kontaktów) sacrum chrześcijańskie, by w ten sposób utwierdzić swą pozycję w walce o rząd dusz w mieście.

Przyczyny powrotu do czci dawnych bogów są ukazane raczej stereotypowo: zaraza i pomór bydła miały zostać wykorzystane przez pogańskich kapłanów do

${ }^{10}$ Według Ebona apostazja w Wolinie miała być prędko zażegnana pod wpływem uznanego za karę niebios za ten grzech pożaru miasta (Ebo III, 1) opisanego też w VP oraz w odmiennym kontekście Herborda. Szerzej o wolińskiej apostazji i jej interpretacji we wszystkich trzech utworach zob. S. Rosik 2010, s. 353-357. 
uzasadnienia konieczności ponowienia zakazanych przez św. Ottona kultów (Herbord III, 16; por. Rosik 2010, s. 358 i n.). Samo zaś pozostawienie czci wobec Chrystusa w sferze publicznej religii miało dokonać się na zasadzie mirakulum, niemożności rozbicia kościelnego ołtarza i paraliżu, jaki miał dotknąć ważącego się na tę próbę destrukcji pogańskiego kapłana (VP III, 5; Ebo III, 1; Herbord III, 16). I ten motyw ma charakter topiczny, a niesie istotne przesłanie, iż Pomorzanie musieli liczyć się już z wkroczeniem chrześcijańskiego Boga w ich historię. Przesłanie to w pierwszym rzędzie oddaje pogląd strony chrześcijańskiej ${ }^{11}$, ale liczyć się należy z jego zbieżnością z wyobrażeniami „barbarzyńców”, a konkretnie adopcją obcej dotąd w ich rozumieniu siły nadprzyrodzonej do własnego panteonu dla zapewnienia sobie jej opieki. W tej konkretnej sytuacji znaczenie miał fakt, iż Bóg chrześcijański patronował zwycięskiej politycznie i militarnie stronie, której zwierzchność przyszło respektować mieszkańcom Szczecina (zwłaszcza Herbord II, 5).

W analizie zaistniałych wówczas w naododrzańskim mieście stosunków religijnych kluczowe znaczenie ma uwzględnienie genezy i specyficznych cech kultu Trzygława, a szczególnie zakresu przypisywanych mu kompetencji. To bowiem istotny kontekst dla oceny faktycznego znaczenia wprowadzenia do życia religijnego Pomorzan elementów chrześcijaństwa w ramach procesu dostosowywania sfery kultu do dynamicznie zmieniających się warunków społecznych na etapie postępującej (nieraz pod militarnym przymusem) integracji z kręgiem politycznym i kulturowym łacińskiej Christianitas jeszcze przed ostateczną likwidacją rodzimej, słowiańskiej, organizacji kultowej w sferze publicznej i zastąpieniem jej strukturami kościelnymi.

Trzygław rysuje się w świetle źródeł pisanych jako suweren panteonu (Ebo III, 1: summus paganorum deus; por. Strzelczyk 2007, s. 216), radykalnie dystansujący pod względem zażywanej czci pozostałe istoty nadprzyrodzone czczone przez szczecinian, podobnie jak np. znany współcześnie z Arkony rugijski Świętowit (Strzelczyk 2007, s. 207-210). Nieraz ten zaznaczający się w schyłkowej fazie wierzeń połabsko-pomorskiej ludności układ w sferze sacrum traktuje się w nauce jako henoteizm (Urbańczyk 1991, s. 105), a nawet rodzaj monoteizmu (Proházka 1958, s. 155). Jednakże przypisywanie tym społecznościom tego rodzaju systemów religijnych jest o tyle wątpliwe, że wyznawcy Trzygława czy Świętowita najpewniej nie negowali istnienia bogów sąsiadów. W tej sytuacji celniejszym określeniem na uprzywilejowanie jednego bóstwa w ramach kultu uprawianego w konkretnej słowiańskiej społeczności wydaje się zatem monolatria (Rosik 1995, s. 107).

Tak silna pozycja Trzygława sprzyjałaby z perspektywy analizy funkcjonalnej tendencji do jego utożsamienia z Chrystusem na zasadzie analogii do znanego z doby antyku zjawiska interpretatio Romana vel graeca bóstw z różnych kręgów etnicznych i kulturowych (Zeus - Jowisz itd.), a tymczasem ustanowiona

11 W Pyrzycach według Herborda sami poganie mieli uznać, że nie mogą oprzeć się Bogu chrześcijan, który ich zewsząd przyciąga, aczkolwiek trudno nie odnaleźć w tym sformułowaniu literackiej kreacji postawy nawracanej ludności, na co wskazuje też nasycenie całego opisu pierwiastkiem biblijnym (Herbord II, 14; Rosik 2010, s. 215). 
w nadodrzańskim mieście koegzystencja czci obu tych postaci utrwalała u szczecinian przekonanie o ich odrębności. To nieutożsamienie obu niebiańskich postaci stanowi zatem istotną przesłankę w dyskusji nad genezą policefalizmu słowiańskich idoli, przemawiającą przeciwko skądinąd i tak już wątpliwej tezie wyjaśniającej pojawienie się trójgłowego idola jako próbę stworzenia słowiańskiej wizji Trójcy Świętej (tak np. Łowmiański 1979, s. 195; krytyka tego stanowiska: Rosik 1995, s. 70-74). Pesymizm tej oceny nie podważa jednak dobrze ugruntowanej źródłowo tezy, że ewolucja schyłkowych wierzeń i kultów Słowiańszczyzny połabsko-pomorskiej następowała $\mathrm{w}$ dialogu $\mathrm{z}$ religiami sąsiadów.

$\mathrm{Z}$ jednej strony wspomniany policefalizm idoli łączy się z partycypacją połabsko-pomorskich społeczności w wykraczającym poza strefę Bałtyku kulturowym kręgu, roboczo ujmując, wyznaczonym zakresem penetracji wikińskiej od Wysp Brytyjskich przez Skandynawię i kraje bałtyjskie aż po Ruś (Lamm 1987, s. 219-231; Rosik 1995, s. 34-48). Z drugiej zaś strony zauważalne jest łączenie elementów panteonu Słowian z bytami z kręgu doktryny kościelnej na zasadzie interpretatio Slavica (zob. np. Czarnobóg jako Diabeł) (Helmold I, 52), co stanowi czytelny przykład recepcji pierwiastków chrześcijaństwa w kulturze duchowej słowiańskich społeczności. Obydwa te zasadnicze kierunki poszukiwań mają źródłowe uzasadnienie $\mathrm{w}$ badaniach nad formowaniem się kultu Trzygława. Nawet bowiem negatywna weryfikacja poglądu, iż bóstwo to miałoby powstać na zasadzie słowiańskiej interpretacji Trójcy Świętej, nie przekreśla poszukiwań hipotetycznych wpływów kontaktów z chrześcijaństwem na ostateczny kształt jego kultu.

W świetle przekazu Ebona trzy głowy oznaczały władzę Trzygława nad trzema królestwami: niebios, ziemi i podziemi, a zasłonięcie oczu idola złotą opaską miało uniemożliwić widzenie ludzkich grzechów (Ebo III, 1). Tym samym bóstwo rysuje się jako antyteza Chrystusa nie tylko $\mathrm{z}$ racji analogii w postaci przypisania mu pankosmicznego panowania, lecz także i przede wszystkim z powodu zaślepienia na ludzkie występki. Liczyć się więc należy z możliwością, że zwłaszcza ten drugi wątek to przejaw kreacji obrazu pogańskiego boga w nurcie interpretatio Christiana, aczkolwiek hipotetycznie warto zaznaczyć, iż może kryć się pod nim zbliżona znaczeniowo idea oddzielenia bóstwa od śmiertelników i bytowania w niedostępnej im sferze niebiańskiej.

Warto w tym miejscu też podkreślić, że w szerokim obiegu naukowym zasłonę na oczach i ustach idola określa się mianem „opaski”, której odpowiada w łacińskiej wersji termin cidaris. Tymczasem oznacza on diadem, mitrę bądź zawój ${ }^{12}$. Tym więc, co miało czynić bóstwo obojętnym na ludzkie grzechy, okazuje się insygnium władzy monarszej bądź kapłańskiej, względnie przypominające turban nakrycie głowy, a z kontekstu wynika, że uroczyste. Motyw ten sprzyja podkreś-

${ }^{12} \mathrm{~W}$ wypadku przekazu hagiograficznego dobrą analogią wydają się porównania do odpowiednich miejsc w Wulgacie, w których cidaris występuje w dwóch znaczeniach: jako mitra (Vulgata: Ex 28, 4; Lev 8, 9 i 16, 4) oraz jako zawój (Vulgata: Ez 21, 26; Za 3, 5). 
leniu majestatu bóstwa, a skoro przy okazji - niewykluczone też, że w intencji Ebona: na ironię - owo nakrycie głowy, a raczej głów posągu, utrwalać miało pogrążanie się jego czcicieli w grzechu, to jego wprowadzenie do narracji wzmacnia w niej wydźwięk antytezy Trzygław - Chrystus.

Uwagę przykuwa przy tym wzmianka, iż owa cidaris została wykonany ze złota, którego symbolika odsyła do najwyższej boskości ${ }^{13}$. Na takie miejsce Trzygława $\mathrm{w}$ panteonie szczecinian wskazuje też sporządzenie - według hagiografii Ottona $\mathrm{z}$ Bambergu - z tego kruszcu także innej jego podobizny, niewielkiej figury, będącej przedmiotem kultu samych tylko kapłanów (Ebo II, 13). Została ona według Ebona unicestwiona podczas pierwszej misji Ottona, już po uprzednim publicznym zniszczeniu głównego idola Trzygława w 1124 roku. W tej sytuacji należy wziąć pod uwagę, że znany z relacji Ebona (III, 1) opis posągu tego bóstwa ze złotym nakryciem głowy dotyczy obiektu sporządzonego później, na etapie apostazji szczecinian, której dotyczy odnośna wiadomość. Stąd też jako jedną z alternatywnych hipotez pozostaje mieć na uwadze możliwość, że złota cidaris pojawiła się dopiero w momencie restytucji kultu Trzygława w ramach oficjalnej dwuwiary w Szczecinie, zlikwidowanej w 1128 roku.

W Vita Prieflingensis zawierającej najwcześniejszy opis idola zniszczonego podczas pierwszej misji Ottona nie ma zresztą mowy o tym insygnium władzy czy zawoju, a jedynie wzmiankuje się, że głowy posągu - odesłane zresztą według Vita Preflingensis papieżowi na dowód nawrócenia Pomorzan w 1125 r. po oderwaniu od rozbitego drewnianego kadłuba (VP II, 12) - pokrywało srebro. Symbolika tego metalu przywołuje z kolei świat chtoniczny, nocny, księżycowy (Gieysztor 2006, s. 147-153; Rosik 2010, s. 260 i n. - tu też szersza literatura zagadnienia). Współgra z tą symboliką czarna maść konia Trzygława oraz mitologiczne wątki głoszące jego nocne eskapady konne, a wreszcie mantyczny charakter zwierzęcia (chtoniczność łączy się z wróżbami i wyrocznią - szerzej zob. Słupecki 2003). Wspomniana tu symbolika kolorów stanowi przesłankę do kreślenia rozwoju mitologii Trzygława na zasadzie nawarstwiania się kolejnych znaczeń na boską postać o podziemnej proweniencji. Aczkolwiek z racji specyfiki materiału źródłowego (literackiego) oraz trudności z weryfikacją domniemań odnośnie do znaczenia takiej a nie innej symboliki barw czy szlachetnych kruszców należy podkreślić, że stąpamy w tego rodzaju rozważaniach po nader kruchym lodzie hipotez.

Grunt ów jednak zdecydowanie tężeje w tych dociekaniach w odniesieniu do eksplikacji samego kształtu i imienia szczecińskiego idola, gdyż dowodnie przemawiają one za podniesieniem do rangi głównego bóstwa patronującego nadodrzańskiej społeczności kolejnej dziejowej realizacji - funkcjonującego w kręgu mitologii ludów indoeuropejskich - archetypu góry kosmicznej o trzech wierzchołkach, u Słowian noszącej miano Triglav (ma ona zresztą swą hierofanię w naturze: masyw o tym imieniu w Alpach Julijskich). Trzy wierzchołki kosmicznej góry bądź

\footnotetext{
${ }^{13}$ Szersza analiza symboliki motywów z opisów posągu Trzygława zob. Rosik 2010, s. 258 i n.
} 
kosmicznego drzewa, posadowionego w mitycznym środku świata, by wyznaczać jego oś (axis mundi), upostaciowują trzy sfery: niebo, ziemię i podziemia (Gieysztor 2006, s. 163 n.), a zatem Trzygław jawi się jako personifikacja rzeczywistości ujmowanej tym mitycznym obrazem.

Warto zaznaczyć, że jego istotnym komponentem jest praocean, z którego wynurza się kosmiczna góra, dająca początek całemu światu. W źródłach pisanych odnośnie do szczecińskiego Trzygława brak wprawdzie tego wodnego odniesienia, jednakże sama zbieżność imienia bóstwa $\mathrm{z}$ nazwą mitycznej góry i interpretacja symboliki jego głów w powiązaniu z trójsektorowością kosmosu pozwala na podkreślmy: teraz już hipotetyczne - uwzględnienie kolejnej analogii w postaci obecności akwatycznego komponentu w szerszym kontekście mitologii trójgłowego idola. W mentalnym środowisku szczecinian, obytych wszak z wodnym żywiołem, ów ,praoceaniczny” wątek początków świata znajdował dostateczne podstawy do ewentualnej recepcji.

$\mathrm{Z}$ drugiej strony natomiast sprzyjające dla niej warunki wyznaczał kontekst krajobrazu miasta. Położone było ono na wzniesieniach, z których najwyższe zwane „górą Trzygława” (mons Trigelawi - Ebo III, 1 i 16) mieścić miało jego świątynię, a także siedzibę książęcą ${ }^{14}$. Nic więc dziwnego, że hagiograf uznał to miejsce za środek miasta ${ }^{15}$. Biorąc zaś pod uwagę znaczenie Szczecina jako stolicy ziemi czy prowincji16 ${ }^{16}$ wchodzącej w skład księstwa zachodniopomorskiego, a niewykluczone też że pretendującego swym autorytetem do hegemonii nad sąsiednimi miastami (w tym Wolinem) $)^{17}$, można pokusić się o interpretację roli góry Trzygława jako sakralnego i politycznego centrum ekumeny, wyznaczonego w nawiązaniu do przywołanej w imieniu bóstwa - o czym już wspomniano - góry kosmicznej, której symbolikę streszcza archetyp axis mundi.

$\mathrm{W}$ analogiczny sposób interpretuje się np. mityczne znaczenie Wawelu jako świętej góry, stanowiącej centrum władzy, z którym łączy się mit założycielski Krakowa (Słupecki 1994, s. 185-197). Dobrze komponuje się z tą ścieżką sakralnej waloryzacji wawelskiego wzgórza opływanie go przez Wisłę. Sytuacyjnie można uznać jej toń za symbol wód okalających kosmiczną górę. Do podobnej roli pre-

${ }^{14}$ Według Ebona „góra Trzygława” była nie tylko najwyższa, ale też „środkowa” w ciągu trzech wierzchołków (Ebo III, 1: „...tres montes ambitu suo conclusos habebat, quorum medius, qui et alcior, summo paganorum deo Trigelawo dicatus..."), co wzmacnia pogląd o jej centralnym położeniu w mieście, ale motyw trójki jest tu najpewniej elementem konwencji literackiej, o czym jeszcze poniżej.

${ }^{15}$ Ebo III, 16: „,...montem Trigelawi in media civitate, ubi sedes erat ducis...”

${ }^{16}$ Odpowiada takiej jednostce m.in. określenie provintia w węższym sensie (por. np. Ebo II, 9: „civitas cum adiacente provincia”). W szerszym znaczeniu provincia w hagiografii Ottona odnosi się do całego kraju, np. provincia Pomerania (por. np. Herbord II, 1).

${ }^{17}$ Według mnicha z Prüfening oraz Herborda Szczecin był metropolią całego Pomorza (VP II, 7: „tocius provincie metropolis habebatur”; Herbord II, 5: „totius Pomeraniae metropolis”), Ebon (II, 9) natomiast podkreślił zwierzchność tego ośrodka nad wszystkimi miastami Pomorza: „que principatum omnium Pomeranie civitatum obtinens". Szerzej w sprawie tych literackich wykładni rangi Szczecina zob. np. Banaszkiewicz 1998, s. 293 n.; Rosik 2010, s. 252 i n. 
tendować może w Szczecinie Odra w sąsiedztwie góry Trzygława, aczkolwiek pozostaje uznać ten kierunek refleksji za pozaźródłowy. Jednak i bez tego wodnego kontekstu „góra Trzygława” hipotetycznie może być uznana za urzeczywistnienie idei góry kosmicznej, zwłaszcza w kontekście jej wyboru spośród sąsiednich szczecińskich wzniesień na miejsce dedykowane nadprzyrodzonemu władcy trójsektorowego kosmosu.

Notabene sam Ebon, podając liczby wzgórz w Szczecinie - najpierw cztery (II, 9), a potem trzy (III, 1) - kreował literacki obraz topografii miasta podatny na symboliczną interpretację (ale być może jedynie wprowadzał motywy numeryczne jako element harmonizujący przekaz). Myśl średniowiecznego autora w tym wypadku odwoływała się do schematów porządkujących obraz świata, szeroko zakorzenionych tak $\mathrm{w}$ intelektualnym dziedzictwie kręgów śródziemnomorskiej cywilizacji antyku, jak też pokładach kulturowych współczesnego mu barbaricum. Dlatego nie sposób ostatecznie wyrokować, czy za podaniem przez Ebona podatnych na symboliczną interpretację liczb szczecińskich wzgórz kryje się nawiązanie do konkretu mitów i podań pomorskich.

Nie ma jednak powodu, by wątpić, że do tego kręgu wierzeniowego należał sam Trzygław, a jego imię - czytelne znaczeniowo nawet dziś - dobrze plasuje się w kontekście teonimów odnoszących się do innych wielogłowych bóstw słowiańskich (często z cząstką '-vit'), jak Świętowit czy Rugiewit, o równie klarownej etymologii. Przyjmuje się, że nazwy te mają dość późną metrykę i wykształciły się wraz z dezintegracją dawnych kultów plemiennych w XI-XII w., a przez to ewolucją systemu wierzeń u Słowian nadmorskich. Śladem takich przekształceń może być obserwowalne w XI w. zastąpienie imienia Swarożyca - czczonego także u Słowian wschodnich - mianem Radogosta (być może początkowo będącego lokalnym przydomkiem Swarożyca) (Urbańczyk 1991, s. 26-31). Nowe kształty naczelnych bóstw miałyby wciąż szereg cech i atrybutów wcześniejszych postaci panteonów i stąd nie dziwi obecność pewnych zbieżności kultu Trzygława z obrzędowością m.in. Swarożyca (zwłaszcza hippomancji) (zob. np. Słupecki 2003).

Uderza jednak w wypadku Trzygława, bóstw Rugian czy Jarowita, wyraźna wspomniana już - tendencja monolatryczna, co czytelnie unaocznia umieszczanie w świątyni, tradycyjnie zwanej kąciną, jednego tylko idola. Czczone w ten sposób boskości mają kompetencje do władania całym uniwersum, na co wskazuje także symbolika liczby głów bądź twarzy ich posągów: czterogłowego Świętowita, podobnie jak Rugiewita o siedmiu obliczach ${ }^{18}$. Nadrzędna cecha policefalnych bóstw to wszechwidzenie, wszechkompetencja, która odbiera rację bytu innym istotom boskim w systemie wierzeń i kultu. Mogą one przetrwać co najwyżej na znacznie niższym statusie - pomocniczym, a przez to podkreślającym wyjątkową rangę suwerena, jak dioskuryczna para towarzysząca Rugiewitowi (Banaszkiewicz 1996).

18 Jarowit odpowiada - ze względu na znaczenie imienia - Świętowitowi, jednak o liczbie głów jego posągu nic nie wiadomo (zob. np. Strzelczyk 2007, s. 85). 
W obliczu zaś terytorializacji zakresu władzy naczelnego bóstwa, związania go z konkretną wspólnotą, liczyć się należy ze szczególnym znaczeniem czci tego, a nie innego idola, jako hierofanii hic et nunc złączonej z konkretnym sanktuarium i miejscem wyroczni, stanowiącym centrum plemiennej czy skupionej wokół ośrodka miejskiego ekumeny.

Trudno w tej sytuacji uprzywilejowania w kulcie jednego tylko bóstwa nie brać pod uwagę naśladownictwa przez Słowian wzorców chrześcijańskich, zwłaszcza gdy uwzględni się pojmowanie Chrystusa/Boga na zasadzie plemiennej, np. jako „Boga Niemieckiego” czy „Boga chrześcijan”, rozumianego jako mistycznego suwerena jednej konkretnej wspólnoty złączonej własnym prawem i obrzędowością religijną. Mamy tu wszak do czynienia z kategoriami umysłowymi tzw. barbarzyńców, u których wspólnota plemienna wyrażała się właśnie przez partycypację w jednym kulcie przy naturalnym wyłączeniu z niego osób obcych (np. Modzelewski 2004, s. 356-365).

Tak uformowany kult Trzygława - wróćmy do sytuacji w Szczecinie między misjami Ottona z Bambergu - stanowił zatem alternatywę dla czci Boga chrześcijańskiego. Z perspektywy teologicznej czy mitologicznej, jak już wyżej wspomniano, wprowadzenie obu kultów oznaczało swego rodzaju znoszenie się kompetencji obu najwyższych boskich istot. Pozostaje wobec tego zatem podkreślić, że zwłaszcza w obliczu ówczesnej dynamiki przemian religijnych nie dochodziło do wypracowywania na gorąco jakichś nowych spójnych systemów mitologii, ale koncentrowano się na samej modernizacji sfery kultu. Jej kierunek dyktowały najpewniej co najmniej dwa czynniki.

Po pierwsze, wziąć należy pod uwagę przekonanie Pomorzan o skuteczności czci oddawanej chrześcijańskiemu Bogu, a w konsekwencji okazywanie przez nich respektu dla przestrzeni sakralnej kościoła $\mathrm{z}$ ołtarzem jako miejscem hierofanii. W szerszej perspektywie zapewne liczyła się też potęga kręgu chrześcijańskiego, jego ekspansja polityczna i militarna nad dolnym biegiem Odry i w jej ujściu; Pomorzan nie stać było na nieliczenie się z Bogiem ich zwycięzców.

Po drugie, warto odnieść się do rozdarcia społeczności szczecinian w wyniku misji Ottona. Wprawdzie głoszony przez niego Bóg określany miał być „Niemieckim" (Teutonicus Deus) (Ebo III, 1), a przez to jawić się jako obcy, niemniej jednak dla wielu mieszkańców nadodrzańskiej metropolii takowy już nie był. Oficjalne włączenie czci Chrystusa do sfery tamtejszego kultu miało więc najpewniej na celu zażegnanie rozłamu wewnętrznego w mieście spowodowanego akcesją części jego mieszkańców do wspólnoty kościelnej.

Efektem takiego ułożenia stosunków religijnych w Szczecinie, jak już wspomniano, okazało się uwydatnienie odrębności Trzygława i Chrystusa, zgodne poniekąd $\mathrm{z}$ chrześcijańską teologią, co $\mathrm{z}$ kolei sprzyjało - po ostatecznym zaprowadzeniu chrześcijaństwa na Pomorzu - ewentualnemu diabolizowaniu Trzygława. Czytelny przykład w tej mierze - aczkolwiek dość późny, bo z 2 połowy XV w. - przynosi Liber sancti Jacobi z prepozytury w Szczecinie, w której to 
księdze Trzygław określony został jako „nieprzyjaciel rodzaju ludzkiego” oraz, pogański w domyśle, „bóg bądź raczej diabeł”19.

Oczywiście poruszamy się w tym wypadku w kręgu hipotez, gdyż tego rodzaju diabolizacja Trzygława mogła powstać na podstawie trwałego funkcjonowania w kulturze umysłowej środowisk chrześcijańskich gotowych matryc biblijnych, sprzyjających tego rodzaju interpretacji pogańskiego bóstwa niezależnie od ewentualnego oddziaływania, domniemanej, sięgającej czasów zaszczepiania chrześcijaństwa na Pomorzu, tradycji. Brak definitywnego rozstrzygnięcia tej godnej dalszych badań kwestii nie wpływa zasadniczo na stanowiący istotny cel powyższych refleksji ogląd zjawisk z lat dwudziestych XII wieku.

W podsumowaniu zaś tego zakresu dociekań pozostaje podkreślić znaczenie misji ewangelizacyjnej z lat 1124-1125 w wywołaniu podziału społeczności Szczecina na wyznawców albo Chrystusa, albo Trzygława, co doprowadziło następnie w tym mieście do próby adopcji do rodzimego, słowiańskiego, systemu religijnego kultu obcego, chrześcijańskiego, sacrum. Po trzech latach Otton z Bambergu zakończył ten eksperyment rekonwersją apostatów. Samo jego wystąpienie uzmysławia jednak, jak dalece w wymiarze kultury duchowej zaawansowany był dialog między kręgiem barbaricum i chrześcijaństwa na Pomorzu nie tylko w ramach elit władzy, które względnie łatwo mogły odnaleźć się w nowym porządku społecznym zaprowadzanym po chrystianizacji ${ }^{20}$, ale też nawet $\mathrm{w}$ wypadku najzagorzalszych zwolenników dawnego ładu świata.

\section{LITERATURA}

Źródła

Adam

Magistri Adam Bremensis Gesta Hammmaburgensis Ecclesiae Pontificum, wyd. B. Schmeidler, MGH, Scriptores rerum Germanicarum in usum scholarum, Hannover-Lipsk 1917. Ebo

Ebo, Żywot św. Ottona biskupa bamberskiego, wyd. J. Wikarjak, wstęp i oprac. K. Liman, MPH s.n., t. 7, cz. 2, Warszawa 1974.

Ekkechardi Uraugiensis chronica

Ekkechardi Uraugiensis chronica, wyd. D.G. Waitz, MGH, Scriptores, t. 6, Hannoverae 1844.

Heinrici de Antwerpe Tractatus de captione urbis Brandenburgensis

Heinrici de Antwerpe Tractatus de captione urbis Brandenburgensis, wyd. O. Holder-Egger, Monumenta Germaniae Historica Scriptores, t. 25, Hannover 1880.

Helmold

Helmoldi presbyteri bozoviensis Chronica Slavorum, wyd. B. Schmeidler, MGH. Scriptores rerum Germanicarum in usum scholarum, Hannoverae 1937.

19 Otton z Bambergu i jego towarzysze „contra inimicum humani generis Trigulaum, quasi trium populorum videlicet Stetinensium, Pomeranorum et Slavorum deum vel pocius dyabolum, vexillis crucifixi Iesu armati processerunt" (za: Petersohn 1962, s. 345-347).

${ }^{20}$ Warto przypomnieć, że członkowie zachodniopomorskich elit z księciem Warcisławem na czele byli już po części na etapie misji św. Ottona ochrzczeni i wspomagali jego działalność. 
Herbord

Herbord, Dialog o życiu św. Ottona biskupa bamberskiego, w: MPH s.n., t. 7, cz. 3, wyd. J. Wikarjak, VP wstęp i oprac. K. Liman, Warszawa 1974.

Die Prüfeninger Vita Bischof Ottos I. von Bamberg nach der Fassung des Großen Österreichischen Legendars, Monumenta Germaniae Historica, Scriptores Rerum Germanicarum, wyd. J. Petersohn, Hannover 1999.

Vulgata

Biblia Sacra juxta Vulgatam Clementinam. Editio electronica, wyd. M. Tvveedale, Londini 2005.

\section{LITERATURA}

Banaszkiewicz J. 1996, Pan Rugii - Rugiewit i jego towarzysze z Gardźca: Porewit i Porenut (Saxo Gramatyk, Gesta Danorum, XIV, 39, 38-41), w: Z. Kurnatowska (red.), Stowiańszczyzna w Europie średniowiecznej, t. 1, Wrocław, s. 75-82.

- 1998 Polskie dzieje bajeczne mistrza Wincentego Kadtubka, Wrocław.

Demm E. 1970, Reformmönchtum und Slawenmission im 12. Jahrhundert. Wertsoziologisch-geistesgeschichtliche Untersuchungen zu den Viten Bischof Ottos von Bamberg, Lübeck-Hammburg.

Gieysztor A. 2006, Mitologia Słowian, wstęp K. Modzelewski, oprac. A. Pieniądz, posłowie L.P. Słupecki, Warszawa.

Haarländer S. 2000, Vitae episcoporum. Eine Quellengattung zwischen Hagiographie und Historiographie, untersucht an Lebensbeschreibungen von Bischöfen des Regnum Teutonicum im Zeitalter der Ottonen und Salier, Stuttgart, s. 527-535.

Lamm J.P. 1987, On the cult of multiple-headed gods in England and the Baltic area, Przegląd Archeologiczny 34 , s. 219-231.

Liman K. 1975, Dialog Herborda. Ze studiów historycznoliterackich nad biografia tacińska XII wieku, Poznań.

Miś A.L. 1997, Przedchrześcijańska religia Rugian. Slavia Antiqua, 38, s. 105-149.

Petersohn J. 1962, Zum mittelaterlichen Kulteinfluss Bamberg auf Pommern. Heinrichs- und Kunigundenverehrung in Stettin., Bericht des Historischen Vereins Bamberg, 98, s. 345-347.

- 1966, Apostolus Pomeranorum. Studien zur Geschichte und Bedeutung des Apostelepithetons Bischof Otto I. von Bamberg, Historisches Jahrbuch 86, z. 2, s. 257-294.

- 1999, Einleitung, w: Die Prüfeninger Vita Bischof Ottos I. von Bamberg nach der Fassung des Großen Österreichischen Legendars, Monumenta Germaniae Historica, Scriptores Rerum Germanicarum, wyd. J. Petersohn., Hannover, s. 1-43.

Procházka V. 1958, Organisace kultu a kmenove zřizeni polabsko-pobaltskych slovanů, Vznik a počatki slovanů 2, s. 145-167.

Rosik S. 1995, Udziat chrześcijaństwa w powstaniu policefalnych posagów kultowych u Stowian zachodnich, Wrocław (= Prace Historyczne 17).

- 2010, Conversio gentis Pomeranorum. Studium świadectwa od wydarzeniu (XII wiek), Wrocław.

Słupecki L.P. 1994, Slavonic Pagan Sanctuaries, Warsaw.

- 2003, Wrożbiarstwo pogańskich Stowian, w: M. Dulinicz (red.), Stowianie i ich sąsiedzi we wczesnym średniowieczu, Warszawa-Lublin, s. 73-80.

Strzelczyk J. 2005, Einleitung, w: Heiligenleben zur Deutsch-Slawischen Geschichte. Adalbert von Prag und Otto von Bamberg, (wyd.) L. Weinrich, współpraca J. Strzelczyk, w: Ausgewählte Quellen zur Deutschen Geschichte des Mittelalters, t. 23, (red.) H.W. Goetz, Darmstadt, s. 18-26.

- 2007, Mity, podania i wierzenia dawnych Stowian, Poznań.

Urbańczyk S. 1991, Dawni Stowianie. Wiara i kult, Wrocław-Warszawa-Kraków. 